\title{
Healthcare expenses for poor households, how can large- scale poverty reduction programs help?
}

\author{
Nguyen Thanh Nhan \\ AISDL
}

28-05-2021

Three articles below show us how can poor households deal with healthcare expense and how can social-economic development programs change the time spending on travel time to healthcare facilities of ethnic minority households.

For the first article: "Coping with health care expenses among poor households: evidence from a rural commune in Vietnam" [1], The authors have explored people's coping mechanisms for paying health-care expenses and examined the effects of such expenditures on economic and health stability in a rural commune of Hanoi. With the "Doi Moi" economic reforms, Vietnam transitioned from a state-funded health-care system to a private user-fee system. For both public and private health-care operations, out-ofpocket fees have become a significant source of funding. Outcome measures included reported episodes of illness, inpatient, outpatient, and self-treatments, out-of-pocket expenditures, and health-care cost funding sources. Inpatient treatments were paid for with loans by households of all income levels; outpatient treatments were paid for with loans by the poor and near-poor more than the non-poor. In comparison to low-cost therapies, the use of loans is increased for really high-cost health treatments for people of all socioeconomic groups, but particularly for the poor and near-poor.

The second article: "Effect of health expenses on household capabilities and resource allocation in a rural commune in Vietnam" [2] is the next section of the first one, its goal is to re-conceptualize the influence of medical costs on households flourishing in terms of "basic capacities." Households with inpatient treatment and higher levels of outpatient therapy lowered investments in fundamental capacities, as demonstrated by decreased consumption of food, education, and production methods, compared to households without inpatient treatment and lower levels of outpatient therapy. The lowest income quartile experienced the greatest drop. There were no reductions in any quartile with inpatient or high-level outpatient treatment. 
The third article assesses the impacts of a program entitled "Socio-economic Development for the Communes Facing Greatest Hardships in the Ethnic Minority and Mountainous Areas" [3] on households in the project area. The program had a favorable influence on a number of key outcomes for ethnic minority households, including productive asset ownership, household durables ownership, and rice productivity, according to our findings. They had beneficial effects on agricultural income, household total income, and household per-capita income, among other higher-order outcomes. Poverty among minority households in treatment communes fell substantially faster than in control communes, which is a notable finding. Finally, compared to households in control communes, ethnic minority households spent less time traveling to health facilities.

Through this, it can be seen that the economic conditions and the level of access to health care services of poor people in mountainous areas still face many shortcomings and difficulties. Therefore, there should be more economic development programs and healthcare support for them.

\section{Note}

This preprint is supplementary document for the research project "The rise of research on development economics in Vietnam SSHPA 2008-2020 dataset" [4]. Employing the Mindsponge though process $[5,6]$, the research project aims to provide a comprehensive review of development economics field in Vietnam from 2008 until 2020.

The openness of this preprint is a support for open science. We proactively endorse the concept of reusability of open data $[7,8]$. We believe the practice will help to prevent our study from potential shortcomings [9], and to inform socio-economic studies and policies at lower costs [10].

\section{References}

[1] Nguyen, K. T., Khuat, O. T. H., Ma, S., Pham, D. C., Khuat, G. T. H., \& Ruger, J. P. (2012). Effect of Health Expenses on Household Capabilities and Resource Allocation in a Rural Commune in Vietnam. PLoS ONE, 7(10), e47423. doi:10.1371/journal.pone.0047423

[2] Cuong, N. V., Tung, P. D., \& Westbrook, D. (2015). Do the poorest ethnic minorities benefit from a large-scale poverty reduction program? Evidence from Vietnam. 
The Quarterly Review of Economics and Finance, 56, 3-14. doi:10.1016/j.qref.2014.09.010

[3] Nguyen, K. T., Hai Khuat, O. T., Ma, S., Pham, D. C., Hong Khuat, G. T., \& Ruger, J. P. (2012). Coping with health care expenses among poor households: Evidence from a rural commune in Vietnam. Social Science \& Medicine, 74(5), 724-733. doi:10.1016/j.socscimed.2011.10.027

[4] Ho, M. T. (2020). The rise of research on development economics in Vietnam SSHPA 2008-2020 dataset [Dataset]. Open Science Framework. Retrieved from https://osf.io/32q89/; DOI: 10.17605/OSF.IO/32Q89.

[5] Vuong, Q. H., \& Napier, N. K. (2015). Acculturation and global mindsponge: an emerging market perspective. International Journal of Intercultural Relations, 49, 354-367.

[6] Vuong, Q. H. (2016). Global mindset as the integration of emerging socio-cultural values through mindsponge processes: A transition economy perspective. In J. Kuada (ed.) Global Mindsets: Exploration and Perspectives (pp. 109-126). London: Routledge.

[7] Vuong, Q. H. (2017). Open data, open review and open dialogue in making social sciences plausible. Nature: Scientific Data Updates. URL: <http://blogs.nature.com/scientificdata/2017/12/12/authors-corner-opendata-open-review-and-open-dialogue-in-making-social-sciences-plausible/> .

[8] Vuong QH. (2019). Breaking barriers in publishing demands a proactive attitude. Nature Human Behaviour, 3(10), 1034, DOI: 10.1038/s41562-019-0667-6.

[9] Vuong, Q. H. (2018). The (ir)rational consideration of the cost of science in transition economies. Nature Human Behaviour, 2(1), 5, DOI: 10.1038/s41562-017-0281-4.

[10] Vuong, Q. H. (2020). Reform retractions to make them more transparent. Nature, 582(7811), 149, DOI:10.1038/d41586-020-01694-x 